\title{
CARVALHO, Ana Margarida de. Não se pode morar nos olhos de um gato. Porto Alegre: Dublinense, 2018. 384p.
}

Antônio Martins da Silva Júnior

Universidade Estadual de Londrina (UEL), Londrina, Paraná / Brasil antonio.martins@uel.br

http://orcid.org/0000-0001-5264-7517

Ana Margarida de Carvalho, escritora e jornalista portuguesa nascida em Lisboa, no ano de 1969, estreou na ficção em 2013 com o livro O que importa a fúria do mar, despontando no mercado editorial como uma das romancistas cuja potência artística mais promete no cenário da novíssima ficção portuguesa. Em 2016, Carvalho publicou o livro que, até então, podemos chamar de sua obra-prima: Não se pode morar nos olhos de um gato, lançado no Brasil com primoroso projeto gráfico pela Editora Dublinense, de Porto Alegre, em 2018, chegando a este lado do Atlântico como livro premiadíssimo, finalista do Oceanos de 2017.

Não vá o leitor se enganar pensando que Não se pode morar nos olhos de um gato trata-se de um romance convencional sobre náufragos e naufrágios. Com um título inspirado no poema do desamor, do poeta Alexandre O'Neill, Ana Margarida de Carvalho teceuma trama elaborada em torno de um grupo de oito sobreviventes do naufrágio de um navio negreiro clandestino. Um grupo bastante heterogêneo, diga-se de passagem, perdido em uma praia intermitente e desabitada, situada em alguma ilha esquecida pela civilização no Atlântico. A inspiração poética não acaba no título, a autora concebe uma obra ímpar da Literatura Portuguesa Contemporânea, com uma profundidade poética encontrada em pouquíssimos romances, tendo imagens literárias riquíssimas, dotadas de uma potência artística avassaladora.

Ainda, empregando uma linguagem afiada e recheada de referências ao Cinema, à TV e à Literatura, é impossível não associar a imagem 
profanada de Nossa Senhora de Todas as Angústias ao personagem Wilson do filme norte americano Cast away (2000), do cineasta Robert Zemeckis; assim como é impossível não relacionar a personagem Maria Clara ao romance Grande sertão: veredas, de João Guimarães Rosa. Vale lembrar que as referências ao romance de Rosa vão além, já que o trecho "viver é um negócio perigoso, viu, seu capataz" (CARVALHO, 2018, p. 354) remete à fala emblemática do seu personagem Riobaldo.

Quando o navio negreiro vai a pique, dele escapam apenas o capataz, um criado, um escravo, uma senhora fidalga e sua filha adolescente, um padre, um estudante e um bebê negro. Oito vidas que se vêm cara a cara, confrontando diariamente suas diferenças, seus medos e seus passados obscuros, em uma sucessão de eventos adversos. Cada revés soma uma nova tragédia à suas tragédias individuais e à grande tragédia coletiva que vivem. Confinados em uma praia sem o básico necessário para uma sobrevivência digna, obrigados ao abrigo comum de uma gruta precária toda vez que a maré sobe e ocupa a estreita faixa de areia que serve de palco para este drama. Esse é o microcosmos composto por Ana Margarida em sua obra-prima. Todo este drama que se desenvolve em algumas centenas de páginas é observado pelo olhar vazio de uma imagem de madeira de Nossa Senhora de Todas as Angústias - contempladora das agruras vividas por este pequeno grupo, cada vez mais desumanizado, que erra em um purgatório cercado pela água salgada e pelo céu luminoso -, que acompanha, em especial, a vida de um determinado personagem como uma juíza eloquente em sua mudez, ou, talvez, uma testemunha silenciosa e conivente.

Em nove capítulos, Carvalho constrói, minuciosamente, cada personagem em idas e vindas através de suas histórias, tal como é o movimento das marés, constituindo uma das tantas imagens relativas ao mar, como bem observa o escritor gaúcho Reginaldo Pujol Filho no texto de orelha da edição brasileira. Utilizando o recurso da analepse, a escritora esmiúça profundamente as vidas de seus personagens, analisa suas motivações e caráter; levantando cada pedra, cada grão de areia de suas vidas em uma narrativa crua, e ao mesmo tempo lírica, sobre personagens complexos, sem maniqueísmos, sem tomar partido por um ou por outro, quase nada fica oculto sobre esses sujeitos que vamos conhecendo aos poucos.

A ficção de Carvalho serve não apenas como fonte de gozo estético, mas também como instrumento de análise social e interacional 
dos indivíduos, uma forma de se buscar, no escopo da literatura, a alteridade por meio da observação da experiência do outro enquanto ser dentro de um contexto social. Nesse sentido, o que vemos é uma série de jogos de poder desenvolvidos pelos personagens que nos tira o fôlego e nos faz virar avidamente cada página em busca de um desfecho.

Trata-se, por fim, de um livro denso. Tão denso quanto os temas delicados que aborda, seja de maneira explícita ou tácita. Opressão patriarcal, abandono, abuso sexual, incesto, alienação parental, inúmeros tipos de violência étnica, de gênero, física, psicológica e espiritual confluem entre si. O argumento aparentemente simples do naufrágio de um navio negreiro clandestino no séc. XIX é cenário para o desenlace de uma fina trama, um enredo com personagens que carregam nas costas o peso do mundo e da História, dos papéis sociais que esperamos que desenvolvam. Não se pode falar mais sobre uma narrativa cíclica com avanços e retrocessos, por correr o risco de revelar muito de seu conteúdo; o que cabe dizer, ainda, é que a densidade dos temas abordados, o zelo para com a linguagem com que foi escrito e as imagens evocadas pela escritora fazem de Não se pode morar nos olhos de um gato um do dos maiores romances portugueses da década de 2010, um livro que pode, certamente, ser elencado no rol dos grandes monumentos literários do ainda jovem séc. XXI, por nos colocar a par de tão intenso drama e por se tratar de um desafio em forma de obra literária. Em suma, Não se pode morar nos olhos de um gato pode ser considerado um entre-lugar que medeia o clássico e o contemporâneo, tanto por atualizar os velhos temas do naufrágio, do navegante, do mar e do náufrago na Literatura Portuguesa, como por suas referências muito bem encadeadas aos clássicos da nossa Língua.

\section{Referência}

CARVALHO, Ana Margarida de. Não se pode morar nos olhos de um gato. Porto Alegre: Dublinense, 2018. 384p. 